\title{
FUNCTIONAL TRAITS AND ECOLOGICAL AFFINITIES OF RIPARIAN PLANTS ALONG THE COLORADO RIVER IN GRAND CANYON
}

\author{
Emily C. Palmquist ${ }^{1,5}$, Barbara E. Ralston ${ }^{2}$, Daniel Sarr ${ }^{1,6}$, David M. Merritt ${ }^{3}$, \\ Patrick B. Shafroth ${ }^{4}$, and Julian A. Scott ${ }^{3}$
}

\begin{abstract}
Trait-based approaches to vegetation analyses are becoming more prevalent in studies of riparian vegetation dynamics, including responses to flow regulation, groundwater pumping, and climate change. These analyses require species trait data compiled from the literature and floras or original field measurements. Gathering such data makes trait-based research time intensive at best and impracticable in some cases. To support trait-based analysis of vegetation along the Colorado River through Grand Canyon, a data set of 20 biological traits and ecological affinities for 179 species occurring in that study area was compiled. This diverse flora shares species with many riparian areas in the western USA and includes species that occur across a wide moisture gradient. Data were compiled from published scientific papers, unpublished reports, plant fact sheets, existing trait databases, regional floras, and plant guides. Data for ordinal environmental tolerances were more readily available than were quantitative traits. More publicly available data are needed for traits of both common and rare southwestern U.S. plant species to facilitate comprehensive, traitbased research. The trait data set is free to use and can be downloaded from ScienceBase: https://www.sciencebase.gov/ catalog/item/58af41dee4b01ccd54f9f2ff and https://dx.doi.org/10.5066/F7QV3JN1
\end{abstract}

Resumen.-Análisis de vegetación con base en rasgos son cada vez más frecuentes en los estudios de la dinámica de la vegetación de ribera, tales como cambios en la composición debido a la regulación del caudal, el bombeo de agua y el cambio climático. Estos análisis requieren datos de rasgos de especies recopilados de la literatura y de las floras o medidas de campo originales, lo que hace que la investigación basada en rasgos sea difícil. Para apoyar el análisis basado en los rasgos de la vegetación a lo largo del río Colorado a través del Gran Cañón, una matriz de 20 rasgos biológicos y afinidades ecológicas de 179 especies que se encuentran en esa área de estudio fue compilado. Esta flora de alta diversidad comparte especies con muchas zonas de ribera en el oeste de los EUA e incluye especies que abarcan un amplio gradiente de humedad-sequía. Los datos de la matriz fueron recompiladas de los artículos científicos publicados, informes inéditos, hojas de datos sobre plantas, bases de datos de rasgos existentes, floras regionales y guías de plantas. Los datos para las tolerancias ambientales ordinales eran más fácilmente disponibles que los de rasgos cuantitativos. Se necesitan más datos disponibles al público acerca de los rasgos tanto comunes como poco comunes de especies de plantas del sudoeste de los EUA para facilitar la investigación integral basada en rasgos. El conjunto de los datos de rasgos es de uso gratuito y se pueden descargar en el número ScienceBase: https:/www.sciencebase.gov/catalog/item/ 58af4ldee4b01ccd54f9f2ff and https://dx.doi.org/10.5066/F7QV3JN1

Environmental factors interact with plant traits (e.g., leaf area, rooting depth, seed mass) to influence where, when, and to what extent species may occur within a habitat and across landscapes (Tilman et al. 1997, Lehman and Tilman 2000, Hough-Snee et al. 2015). Analysis of plant traits and environment interactions has provided a way to explore aspects of functional ecology across geographic, environmental, and evolutionary scales. At a global scale, Dolph and Dilcher (1980) used leaf size to describe vegetation assemblage changes in response to climatic changes, while Moles and Westoby (2003) demonstrated that seed size declined by $2-3$ orders of magnitude from the equator to $60^{\circ}$ latitude. Others have used trait-based vegetation analyses to examine trait patterns across environment gradients (Reich and Oleksyn 2004, Cornwell and Ackerly 2009, Lawson et al. 2015), evolutionary patterns in traits (Knight and Ackerly 2003, Moles et al. 2005), or intraspecific variation in traits relative to environmental gradients (de la Riva et al. 2016). Employing trait-based approaches can reveal morphological and physiological similarities among species, provide a quantitative framework for assembly rules for community

\footnotetext{
${ }^{1}$ U.S. Geological Survey, Southwest Biological Science Center, Grand Canyon Monitoring and Research Center, 2255 N. Gemini Drive, Flagstaff, AZ 86001. ${ }^{2}$ U.S. Geological Survey, Office of Science Quality and Integrity, 2255 N. Gemini Drive, Flagstaff, AZ 86001.

${ }^{3}$ U.S. Forest Service, National Stream and Aquatic Ecology Center, 2150 Centre Ave., Bldg. A, Suite 368, Fort Collins, CO 80526

${ }^{4}$ U.S. Geological Survey, Fort Collins Science Center, 2150 Centre Ave., Bldg. C, Fort Collins, CO 80526.

5E-mail: epalmquist@usgs.gov

${ }^{6}$ Deceased.
} 
ecology, and describe global patterns of adaptations (Keddy and Weiher 1999).

Variable hydrology and dynamic channel processes make riparian ecosystems ideal for trait-based analysis and comparisons across physical gradients. Riparian ecosystems are inherently heterogeneous environments that support species with a variety of life history strategies (Naiman et al. 1993). These habitats are distributed globally and occur in many geomorphic settings, as well as in mesic to arid environments. These ecosystems are recognized as key to biodiversity preservation (Naiman et al. 1993), but their integrity is increasingly compromised by effects of flow regulation (Nilsson and Berggren 2000) and alterations in discharge volumes associated with climate change (Palmer et al. 2008, Perry et al. 2012, Seager et al. 2012). Trait-based approaches to riparian vegetation analysis can reveal redundancies in plant traits among plant species and can be used to disentangle functional diversity found in a habitat patch. Understanding how species with similar trait values are distributed along environmental gradients can also be used to identify candidate species that may fill a niche previously occupied by a species that can no longer persist under river regulation or changes in climate (Kyle and Leishman 2009, Stromberg and Merritt 2016).

Trait information has been used for a variety of riparian vegetation analyses, including defining functionally relevant groups of plants (guilds or functional groups) that are expected to respond similarly to environmental resource gradients and/or stressors (Merritt et al. 2010, Hough-Snee et al. 2015, Stromberg and Merritt 2016), evaluating changes in vegetation attributes due to environmental change (Kyle and Leishman 2009, Bejarano et al. 2012), and predicting changes to ecosystem services and ecological functions resulting from vegetation change (Merritt and Bateman 2012). In dryland riparian areas, trait-based analyses are beginning to be used to better understand the impacts of flow regulation and groundwater pumping on riparian vegetation (Bejarano et al. 2012, Merritt and Bateman 2012, Stromberg and Merritt 2016), the results of which could potentially be applied to future scenarios and restoration efforts associated with climate change or changing human water use demands (Harrison et al. 2010).
The previously mentioned examples of traitbased analysis in other systems (Reich and Oleksyn 2004, Cornwell and Ackerly 2009, Lawson et al. 2015) could also be applied to riparian ecosystems to understand patterns and drivers of riparian plant distributions.

To successfully relate trait-based plant groupings to environmental change and ecosystem functions, consistent and complete data about the traits of individual plant species in the flora of interest are required. Data for features measurable on an individual plant, such as height and rooting depth (hereafter "biological traits"), are needed to link vegetation to ecosystem processes (Merritt et al. 2010, Stromberg 2013, Verberk et al. 2013). However, the data most readily available are "ecological affinities," data that describe the general response of a species to an environmental variable, habitat, or resource (e.g., drought tolerance, salinity tolerance). Although these types of data are useful, they often integrate multiple traits and observed environmental relationships, obscuring linkages among those variables and hampering efforts to avoid circularity in cause and effect (Verberk et al. 2013).

Compiling relevant information for traitbased analyses specific to U.S. dryland riparian areas requires extensive literature resources, a large time and staffing commitment, and often original field measurements. Additionally, until a thorough literature search has been conducted, the need for new field measurements (extent of data gaps) is unclear. Thus, open sharing of data that will be useful to many trait-based projects has the potential to increase the efficiency of individual research projects, to identify critical data gaps, and to advance trait-based and functional ecology research. Tremendous effort and resources have been focused on gathering data on the biological traits and ecological affinities of thousands of common species throughout the world as part of a number of trait database projects (e.g., PLANTS, LEDA, TRY, MARIWENN, BROT, FLOWBASE, SID, eHALOPH, and GLOPNET) (Kew Royal Botanic Gardens 2008, Kleyer et al. 2008, Reich et al. 2009, USDA 2010, Baralotto et al. 2011, Aguiar et al. 2013, Paula and Pausas 2013, Boenisch and Kattge 2014, Flowers et al. 2015). Unfortunately, trait data for U.S. dryland riparian areas are not well represented in these databases (Stromberg 2013, 
Hough-Snee et al. 2015). The USDA PLANTS database (USDA 2010) contains information on many desert riparian and upland species, but the data are mostly ecological affinities with categorical or ordinal values that are most applicable in agricultural or cultivation settings. For example, the PLANTS database lists a minimum rooting depth category for many species (useful for horticultural application), but a maximum rooting depth is necessary for understanding relationships between desert riparian species occurrence and water availability (Stromberg 2013). These data are only marginally useful for identifying relationships between vegetation responses and the environment. Other databases that contain measured traits are focused on one particular trait or set of traits, or contain only a few traits of desert riparian species from the southwestern USA. For example, the Seed Information Database (SID) (Kew Royal Botanic Gardens 2008) contains extensive data on seed weights, storage behavior, germination, etc., but does not contain data related to other parts of the plant. Alternatively, TRY: Plant Trait Database (Boenisch and Kattge 2014), LEDA Traitbase (Kleyer et al. 2008), and FLOWBASE (Aguiar et al. 2013) all house a wide variety of trait data but currently have data for only a small percentage of southwestern U.S. plant species. The data set presented here is a starting point for collating traits of these species.

To help fill the information gap in trait data for western U.S. riparian systems, we compiled a data set of 5 biological traits and 15 ecological affinities for 179 herbaceous and woody plant species occurring along the Colorado River through Grand Canyon (Table 1, Supplementary Material 1). For each species in the data set, its family, genus, and species names; species code; wetland indicator status (Lichvar et al. 2014); and values for each of the biological traits and ecological affinities (as available) are listed. Biological traits and ecological affinities were recorded at the species level; subspecies, varieties, and cultivars were not documented separately. Definitions and units of measure for each of the variables are provided (Table 1). Citations for values in the data set are noted, and the complete citation is included in a separate list (Supplementary Material 2).

This data compilation is supporting the development of vegetation-flow response guilds (sensu Merritt et al. 2010) that are being used to examine past and future riparian vegetation change in response to dam operations and climate change in Grand Canyon. In addition, the data are likely to have several applications beyond the Grand Canyon. The Grand Canyon flora comprises species typical of 3 of the 4 western deserts: the Mojave, the Great Basin, and the Sonoran (Phillips et al. 1987). The flora found within riparian habitats along the Colorado River in the Grand Canyon also consists of both native and nonnative species that exhibit a wide range of hydrologic tolerances (submerged to drought tolerant) and includes upland species. This broad representation of western floras will be useful for a spectrum of trait-based analyses and for identifying data gaps in plant traits of western species. Collating the traits for drought-tolerant species that occur in riparian areas will likely be important for understanding and attempting to restore dewatered riparian zones (Beauchamp and Shafroth 2011, Reynolds and Cooper 2011), to refine management of flow regimes (Merritt et al. 2010), and to forecast vegetation response to climate change (Perry et al. 2012, 2013).

Species in the data set include vascular plant species recorded as part of annual riparian vegetation monitoring along the Colorado River between Lees Ferry, Arizona, and the eastern boundary of Lake Mead National Recreation Area, Arizona, as well as species that are known to occur in the study area (Phillips et al. 1987; B. Ralston and E. Palmquist personal observation). The 179 species in the data set represent 122 genera and 37 families (Supplementary Material 1). Forbs (61) and grasses (58) comprise the bulk of the list, but shrubs (33), trees (10), rushes (14), succulents (2), and a sedge (1) are also represented (Table 2, Supplementary Material 1). Reflecting the species composition in the Grand Canyon, there are more native (141) than introduced (38) species. The plants range from obligate wetland species to obligate upland species, reflecting adaptations to the selective pressures associated with strong gradients in moisture availability and flow duration from river's edge to upland, as well as the mosaic pattern of landforms and microhabitats within the riparian area of the Grand Canyon.

The data set contains 5 biological traits (values measurable on an individual plant; e.g., maximum rooting depth) and 15 ecological 


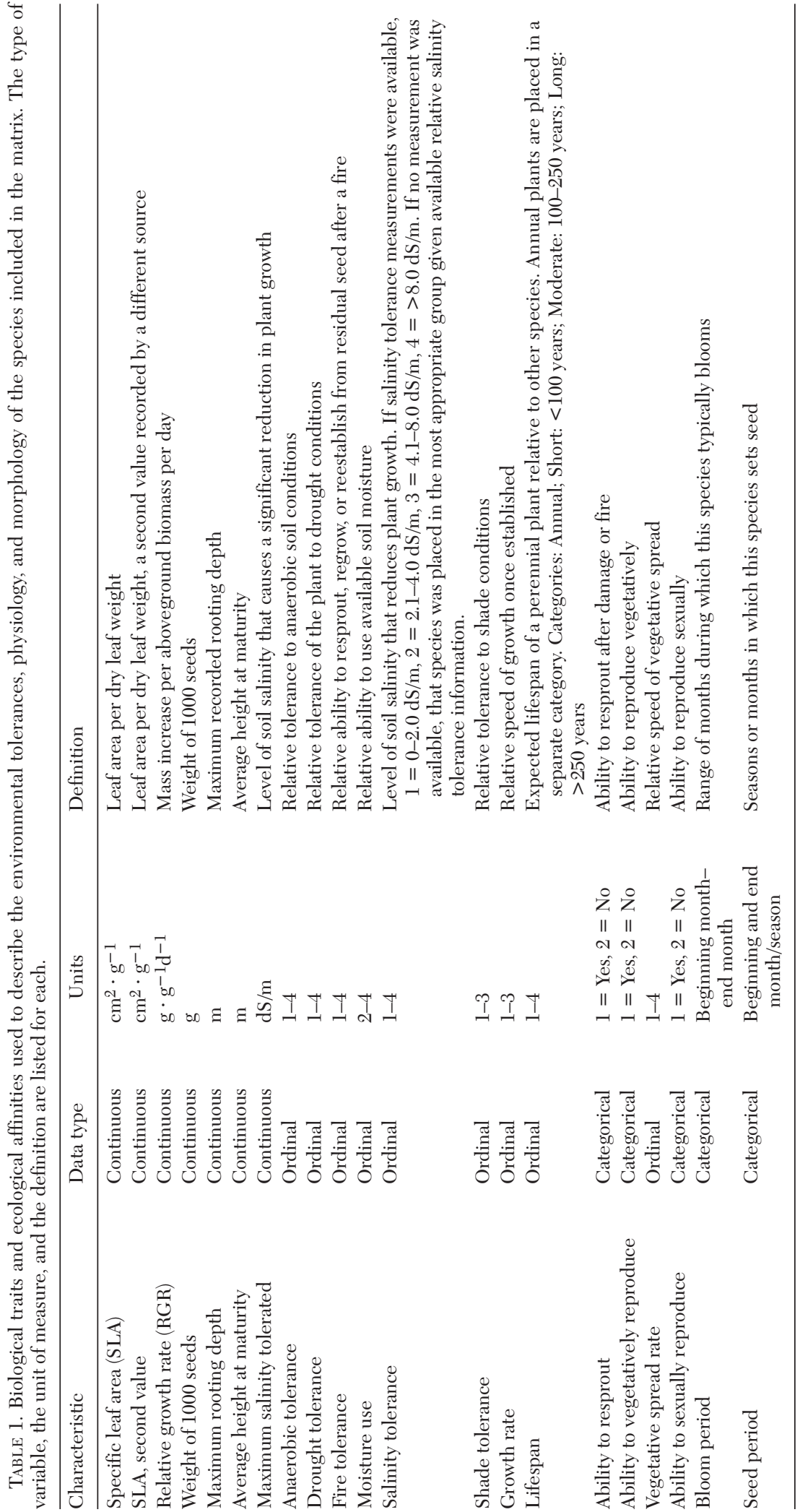


TABLE 2. No. species $=$ number of species included that fall into each functional group (Forb, Grass, Sedge, Rush, Succulent, Shrub, Tree), are considered native or introduced, and have values for all traits (Complete species). All species had at least 4 traits values. Percent $=$ the percentage of the total species represented. Values presented are for the time of publication and are expected to increase in the future. See Supplementary Material 1 for a complete species list at the time of publication.

\begin{tabular}{lcr}
\hline Species group & No. species & Percent \\
\hline Forb & 61 & $34 \%$ \\
Grass & 58 & $32 \%$ \\
Sedge & 1 & $1 \%$ \\
Rush & 14 & $8 \%$ \\
Succulent & 2 & $1 \%$ \\
Shrub & 33 & $18 \%$ \\
Tree & 10 & $6 \%$ \\
Native & 141 & $79 \%$ \\
Introduced & 38 & $21 \%$ \\
Complete species & 6 & $3 \%$ \\
\hline
\end{tabular}

affinities (ecological tolerances; e.g., drought tolerance) (Table 1). A data set consisting entirely of biological traits is preferable to one including ecological affinities, but biological trait data for southwestern plant species are limited. Thus, ecological affinities were used in addition to biological traits. Biological traits and ecological affinities that are likely to be useful for stream flow management and environmental filtering represent the bulk of the data set, such as resiliency and regeneration strategies relative to flood-related inundation, sediment deposition and erosion, and water availability (e.g., anaerobic tolerance, rooting depth, and vegetative propagation). Traits from Westoby's leaf-height-seed (LHS) plant ecology strategy scheme (Westoby 1998) were included for multiple purposes; specific leaf area (SLA) is reflective of resource acquisition and conservation (Reich 2014), height at maturity is associated with light competition and competitive dominance (Westoby 1998), and seed mass is an indicator of regeneration strategy and the ability to recolonize from seed banks or after disturbance (Westoby 1998). Traits that are important for other ecosystem functions but with less direct connection to stream flow management (e.g., litter and temperature traits) are not included.

Fourteen of the variables are categorical or ordinal and 6 are continuous; both biological traits and ecological affinities are represented by both types of data. Specific leaf area is included twice, representing values from different references. The secondary values illustrate how intraspecific variation can be incorporated into the data set. The data set does not include intraspecific variation of the other variables because it was not used in the development of the riparian vegetation-flow response guilds. Currently, each data point is either the only value that could be found or the value that is likely to be most applicable to the Grand Canyon (based on the location of the source study). Data that represent intraspecific variation can be added to the data set as needed and as data become available.

Data were compiled from over 275 references (Supplementary Material 2) and stored as a matrix. Published scientific literature, unpublished government reports and databases, USDA PLANTS (USDA 2010), the Kew Royal Botanic Gardens Seed Information Database (Kew Royal Botanic Gardens 2008), eHALOPH (Flowers et al. 2015), regional floras, and plant guides were all used to fill in as many data points as possible (Supplementary Material 2). Literature searches were conducted online using both a standard search engine and Google Scholar. Search terms included the species name and different phrasing for each trait (e.g., maximum rooting depth, root length, root depth). Species synonyms were also searched for in this manner. Because data for biological traits of southwestern species are incomplete, ecological affinity data from USDA PLANTS (USDA 2010) and other sources were used in addition to trait data with the idea that these data will be replaced with biological trait data as they become available. The authors and several other riparian ecologists with expertise in southwestern U.S. riparian systems reviewed the draft data set to provide professional judgment regarding the trait values, particularly the ecological affinities. If a value for an ecological affinity was judged as unsupported by expert knowledge and did not have associated data (e.g., the affinities that are available on PLANTS), that value was left blank. Many of the values for anaerobic (57\%), drought $(51 \%)$, fire $(59 \%)$, and shade tolerance $(65 \%)$; moisture use (92\%), growth (79\%) and spread rate $(50 \%)$; and resprout (63\%) and seed period (60\%) come from PLANTS (Table 3). Most of the values for seed weight come from the Kew Royal Botanic Gardens Seed Information Database (SID; 98\%). Even so, only 


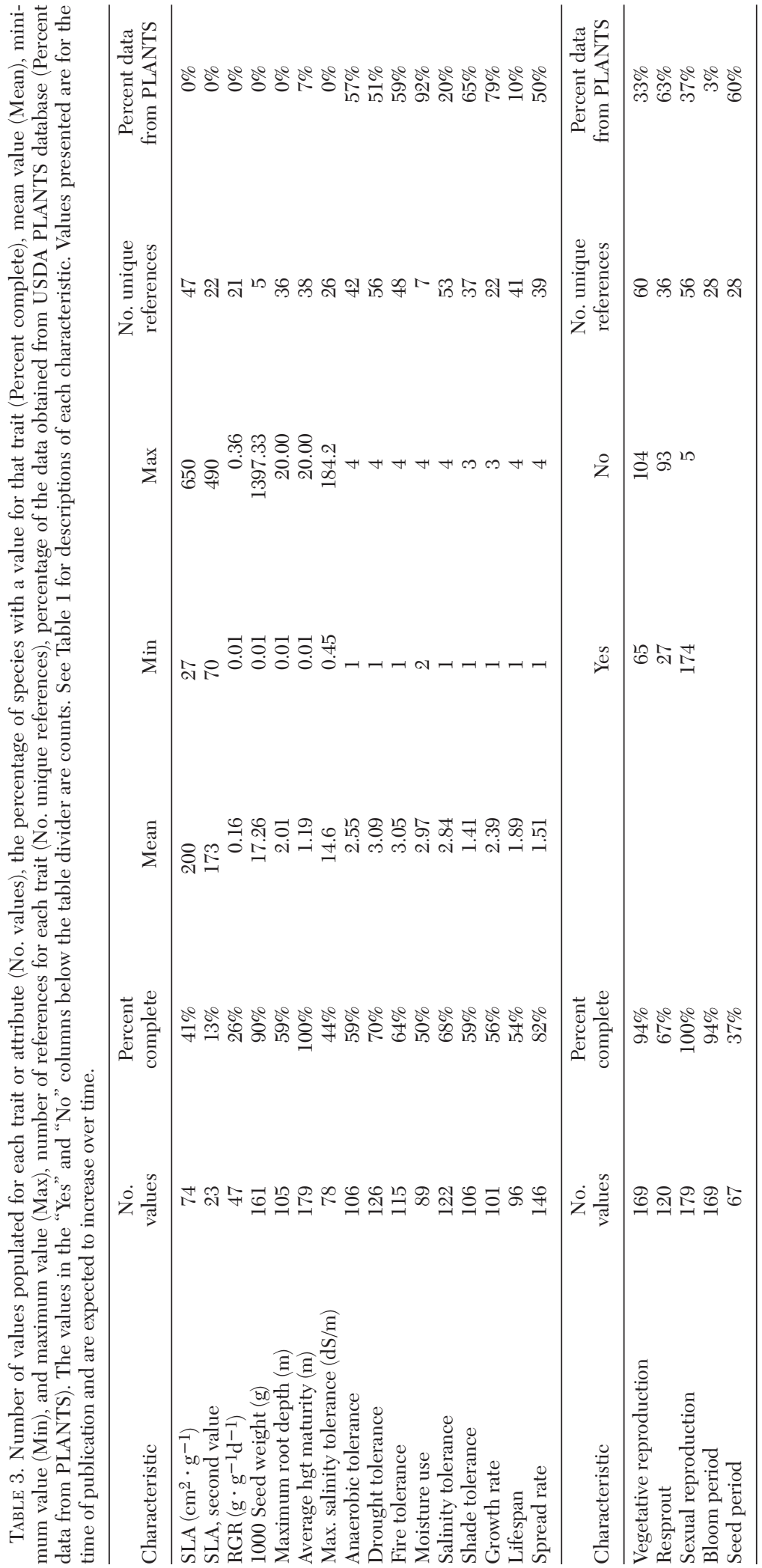


$33 \%$ of the entire data set comes from PLANTS and only $7 \%$ from SID. Data for specific leaf area, relative growth rate, maximum rooting depth, average height at maturity, maximum salinity tolerated, salinity tolerance, lifespan, ability to sexually and vegetatively reproduce, and bloom period were either entirely or mostly from references other than PLANTS (Table 3). No species has only data from either PLANTS or SID. The average number of unique references used for each species is 5.5 (minimum $=1$, maximum $=11)$.

Traits ranged from being complete (average height at maturity and ability to sexually reproduce; 179 entries) to $26 \%$ complete (relative growth rate; 47 entries) (Table 3 ). The ecological affinities were generally available for more species, while the data fields for biological traits were less complete. On average, species have 13.6 data points $($ minimum $=4$, maximum $=20$ ). Less information was typically available for species that are limited in distribution and/or are forbs (e.g., Baccharis brachyphylla and Wislizenia refracta). The most complete information available was for nonnative species of concern (e.g., Bromus tectorum and Salsola tragus), large woody species (e.g., Populus fremontii and Salix gooddingii), prairie species (e.g., Andropogon gerardii and Schizachyrium scoparium), and broadly distributed rangeland species (e.g., Artemisia tridentata and Pascopyrum smithii). More data are needed for the traits of both common and rare southwestern plant species.

Although this effort is intended to be a comprehensive summary of the data available for these species at this time, some hard-to-find sources (not electronic, out of print, etc.) may have been overlooked. Also, the values listed here are not necessarily representative of species across their entire range. Many of the values are point measurements from a certain time and place with limited replication at that site and no replication across the geographic and morphologic range of the species. These data should still be useful for landscape-scale analyses despite these limited numbers of measurements (Kazakou et al. 2014, Ordonez 2014). In particular, seed mass, maximum and reproductive plant height, and specific leaf area are stable enough within most species to allow for analyses between species using a mean value (Kazakou et al. 2014, Ordonez 2014). However, individual values from different data sources for the vegetative plant height of herbaceous species may not be reliable (Kazakou et al. 2014). The ordinal attributes (i.e., anaerobic tolerance, drought tolerance, fire tolerance, moisture use, salinity tolerance, shade tolerance, growth rate, and spread rate) are discretely ordered and are intended to represent the typical response of that species, so they are inherently less precise with respect to intraspecific variation.

This data set will be added to and revised through contributions from other researchers and as new data are collected by our group. Over time, the ecological affinities will be replaced with related biological traits (measurable on an individual) and data added where it is currently missing. For example, quantitative biological trait data are currently being collected by collaborators at Northern Arizona University (McCoy-Sulentic 2016). As the trait data set is updated and expanded, new versions will be added to ScienceBase. Older versions for reference will remain available on the site (Supplementary Material 3). At present there are no plans to add more ecological affinities, though these can be added as they are deemed useful for specific analyses. The data set is free to use and can be downloaded from ScienceBase: https://www.sciencebase .gov/catalog/item/58af4ldee4b01ccd54f9f2ff and https://dx.doi.org/10.5066/F7QV3JN1. Contact information for submitting new data is also listed on ScienceBase.

\section{Supplementary Material}

Three online-only supplementary files accompany this article (scholarsarchive.byu .edu/wnan/vol77/iss1/3).

Supplementary Material 1. List of species included in the traits data set at the time of publication.

Supplementary Material 2. List of references used at the time of publication.

Supplementary Material 3. Data traits matrix (Microsoft Excel file).

\section{ACKNOWLEDGMENTS}

This study was supported by the U.S. Department of the Interior, Bureau of Reclamation through the Glen Canyon Dam Adaptive Management Program, with logistical and managerial support from the U.S. Geological 
Survey's Grand Canyon Monitoring and Research Center. Any use of trade, firm, or product names is for descriptive purposes only and does not imply endorsement by the U.S. government. Thanks to Mark Dixon, Nate Hough-Snee, John Spence, John Stella, and Juliet Stromberg for assessing the variable values, providing excellent feedback on the contents of the matrix, and providing input on the variables researched. Thanks to Thomas Kolb and Miles McCoy-Sulentic for valuable traits discussions and help with vegetation monitoring. Thanks to Robert May for translating the abstract. Thanks to the reviewers for their constructive and useful feedback.

\section{Literature Cited}

Aguiar, F.C., A. Fabião, M.D. Bejarano, D. Merritt, C. Nilsson, AND M.J. Martins. 2013. FLOWBASEa riparian plant traitbase. Instituto Superior de Agronomia, Universidade de Lisboa, Portugal. http://www.isa.ulisboa.pt/proj/flowbase

Baralotto, C., Y. Caraglio, J.-Y. Goret, and D. ScherBERICH. 2011. MARIWENN-Guiana species database. EcoFoG (Joint Research Unit Ecology of Guiana Forests), Center for the Study of Biodiversity in Amazonia.

Beauchamp, V.B., and P.B. Shafroth. 2011. Floristic composition, beta diversity, and nestedness of reference sites for restoration of xeroriparian areas. Ecological Applications 21:465-476.

Bejarano, M.D., M. González del Tánago, D.G. De Jalón, M. Marchamalo, Á. Sordo-Ward, and J. SOLANA-GUTIÉRREZ. 2012. Responses of riparian guilds to flow alterations in a Mediterranean stream. Journal of Vegetation Science 23:443-458.

Boenisch, G., AND J. KatTge. 2014. TRY-plant trait database: quantifying and scaling global plant trait diversity. Max Planck Institute for Biogeochemistry and Diversitas/IGBP.

Cornwell, W.K., AND D.D. ACKerly. 2009. Community assembly and shifts in plant trait distributions across an environmental gradient in coastal California. Ecological Monographs 79:109-126.

de la Riva, E.G., I.M. Perez-Ramos, A. Tosto, C.M. Navarro-Fernandez, M. Olmo, T. Maranon, and R. VILLAR. 2016. Disentangling the relative importance of species occurrence, abundance and intraspecific variability in community assembly: a trait-based approach at the whole-plant level in Mediterranean forests. Oikos 125:354-363.

Dolph, G.E., AND D.L. Dilcher. 1980. Variation in leaf size with respect to climate in the tropics of the Western Hemisphere. Bulletin of the Torrey Botanical Club 107:154-162.

Flowers, T., J. Santos, M. Jahns, B. Warburton, and P. REED. 2015. Halophytes-eHALOPH database. University of Sussex, Brighton, United Kingdom.

Harrison, S.P., I.C. Prentice, D. Barboni, K.E. Kohfeld, J. NI, AND J.P. SUTRA. 2010. Ecophysiological and bioclimatic foundations for a global plant functional classification. Journal of Vegetation Science 21:300-317.
Hough-Snee, N., B. Laub, D.M. Merritt, A.L. Long, L.L. Nackley, B.B. Roper, and J.M. Wheaton. 2015. Multi-scale environmental filters and niche partitioning govern the distributions of riparian vegetation guilds. Ecosphere 6:1-22.

Kazakou, E., C. Violle, C. Roumet, M. Navas, D. Vile, J. KattGe, And E. Garnier. 2014. Are trait-based species rankings consistent across data sets and spatial scales? Journal of Vegetation Science 25: 235-247.

Keddy, P.A., AND E. Weiher, Editors. 1999. Ecological assembly rules: perspectives, advances, retreats. Cambridge University Press.

Kew Royal Botanic Gardens. 2008. Seed Information Database (SID), version 7.1. http://data.kew.org/sid

Kleyer, M., R.M. Bekker, I.C. Knevel, J.P. Bakker, K. Thompson, M. Sonnenschein, P. Poschlod, J.M. Van Groenendael, L. Klimes, and J. Klimesova, et AL. 2008. The LEDA Traitbase-a database on the life history traits of the Northwest European flora. The German Federal Agency for Nature Conservation, Oldenburg, Germany.

Knight, C.A., AND D.D. ACKerly. 2003. Evolution and plasticity of photosynthetic thermal tolerance, specific leaf area and leaf size: congeneric species from desert and coastal environments. New Phytologist 160:337-347.

Kyle, G., And M.R. Leishman. 2009. Functional trait differences between extant exotic, native and extinct native plants in the Hunter River, NSW: a potential tool in riparian rehabilitation. River Research and Applications 25:892-903.

Lawson, J.R., K.A. Fryirs, M.R. Leishman, and S. BONSER. 2015. Hydrological conditions explain variation in wood density in riparian plants of southeastern Australia. Journal of Ecology 103:945-956.

Lehman, C.L., and D. Tilman. 2000. Biodiversity, stability, and productivity in competitive communities. American Naturalist 156:534-552.

Lichyar, R.W., M. Butterwick, N.C. Melvin, and W.N. KirChner. 2014. The National Wetland Plant List: 2014 update of wetland ratings. Phytoneuron 2014-41: $1-42$.

McCoy-Sulentic, M. 2016. Functional traits of riparian plants and plant communities of the Colorado River in Grand Canyon. Master's thesis, Northern Arizona University, Flagstaff, AZ.

Merritt, D.M., and H.L. Bateman. 2012. Linking stream flow and groundwater to avian habitat in a desert riparian system. Ecological Applications 22: 1973-1988.

Merritt, D.M., M.L. Scott, N.L. Poff, G.T. Auble, and D.A. LYTLE. 2010. Theory, methods and tools for determining environmental flows for riparian vegetation: riparian vegetation-flow response guilds. Freshwater Biology 55:206-225.

Moles, A.T., D.D. ACKerly, C.O. Webb, J.C. Tweddle, J.B. Dickie, A.J. Pitman, and M. Westoby. 2005. Factors that shape seed mass evolution. Proceedings of the National Academy of Sciences 102: $10540-10544$.

Moles, A.T., And M. Westoby. 2003. Latitude, seed predation and seed mass. Journal of Biogeography 30:105-128.

Naiman, R.J., H. Decamps, and M. Pollock. 1993. The role of riparian corridors in maintaining regional biodiversity. Ecological Applications 3:209-212. 
Nilsson, C., and K. Berggren. 2000. Alterations of riparian ecosystems caused by river regulation. BioScience 50:783-792.

OrdonEz, A. 2014. Global meta-analysis of trait consistency of non-native plants between their native and introduced area. Global Ecology and Biogeography 23:264-273.

Palmer, M.A., C.A.R. Liermann, C. Nilsson, M. Flörke, J. Alcamo, P.S. Lake, AND N. Bond. 2008. Climate change and the world's river basins: anticipating management options. Frontiers in Ecology and the Environment 6:81-89.

Paula, S., and J.G. Pausas. 2013. BROT: a plant trait database for Mediterranean Basin species, version 2013.06. Centro de Investigaciones sobre Desertificación of the Consejo Superior de Investigaciones Cientificas.

Perry, L.G., D.C. Andersen, L.V. Reynolds, S.M. Nelson, AND P.B. Shafroth. 2012. Vulnerability of riparian ecosystems to elevated $\mathrm{CO}_{2}$ and climate change in arid and semiarid western North America. Global Change Biology 18:821-842.

Perry, L.G., P.B. Shafroth, D.M. Blumenthal, J.A. Morgan, and D.R. LeCain. 2013. Elevated $\mathrm{CO}_{2}$ does not offset greater water stress predicted under climate change for native and exotic riparian plants. New Phytologist 197:532-543.

Phillips, B.G., A.M. Phillips III, And M.A. SchmidtBERnzotT. 1987. Annotated checklist of vascular plants of Grand Canyon National Park. Grand Canyon Natural History Association Monograph No. 7. Grand Canyon, AZ.

REICH, P.B. 2014. The world-wide 'fast-slow' plant economics spectrum: a traits manifesto. Journal of Ecology 102:275-301.

Reich, P.B., D.D. Ackerly, I. Wright, and M. Westoby. 2009. GLOPNET: Global Plant Trait Network. Macquarie University, Sydney, Australia.
Reich, P.B., And J. Oleksyn. 2004. Global patterns of plant leaf $\mathrm{N}$ and $\mathrm{P}$ in relation to temperature and latitude. Proceedings of the National Academy of Sciences 101:11001-11006.

Reynolds, L.V., AND D.J. CoOper. 2011. Ecosystem response to removal of exotic riparian shrubs and a transition to upland vegetation. Plant Ecology 212: 1243-1261.

Seager, R., M. Ting, C. Li, N. Naik, B. Cook, J. Nakamura, AND H. LiU. 2012. Projections of declining surface-water availability for the southwestern United States. Nature Climate Change 3:482-486.

STROMberG, J.C. 2013. Root patterns and hydrogeomorphic niches of riparian plants in the American Southwest. Journal of Arid Environments 94:1-9.

StromberG, J.C., AND D.M. Merritt. 2016. Riparian plant guilds of ephemeral, intermittent and perennial rivers. Freshwater Biology 61:1259-1275.

Tilman, D., J. Knops, D. Wedin, P. Reich, M. Ritchie, and E. Siemann. 1997. The influence of functional diversity and composition on ecosystem processes. Science 277:1300-1302.

[USDa] United States Department of Agriculture. 2010. The PLANTS Database. USDA National Resources Conservation Service.

Verberk, W.C.E.P., G.G.E. VAN NoORdWIJK, AND A.G. HildREw. 2013. Delivering on a promise: integrating species traits to transform descriptive community ecology into a predictive science. Freshwater Science 32:531-547.

Westoвy, M. 1998. A leaf-height-seed (LHS) plant ecology strategy scheme. Plant and Soil 199:213-227.

Received 7 April 2016 Accepted 25 October 2016 Published online 28 February 2017 